\title{
THE WORK OF THE HILL FARMING RESEARCH ORGANISATION, SCOTLAND
}

\author{
P. NEWBOULD \\ Head of Plants and Soils Department, Hill Farming Research \\ Organisation, Bush Estate, Penicuik, Midlothian, Scotland
}

THE Hill Farming Research Organisation (HFRO) was established in 1954 as an independent state-aided institute with a board of management appointed by the Secretary of State for Scotland. It is financed by the Department of Agriculture and Fisheries for Scotland and receives advice on scientific work and on staff management from the Agricultural Research Council in London.

The total staff complement is about 130, of whom 70 are scientists; of the latter, 20 are initiators or project leaders. The headquarters and laboratories are on the Bush Estate six miles from Edinburgh. The Estate is owned by the University of Edinburgh and the twelve university departments and research institutes that use it, in addition to HFRO, jointly constitute the Edinburgh Centre of Rural Economy.

The Organisation has direct control of five farms which offer a range of different soils, vegetation types and climates, so providing an extensive variety of conditions for experimental work. The farms are: House o' Muir, Bush, Midlothian (245 ha) ; Glensaugh, Laurencekirk, Kincardineshire (790 ha) ; the Red Deer Farm (200 ha) at the same location: Lephinmore, Strathlachlan, Argyll (1135 ha) ; and Sourhope, Yetholm, Roxburghshire (1120 ha) .

The aim of the Organisation's work is to improve the economic viability of the production of meat animals from the upland and hill pastoral resources of the United Kingdom. Work falls into two main areas: (1) Research aimed at understanding the biological factors of significance in determining pasture and animal production in hill and upland environments, and (2) the development of systems of animal production based on this improved knowledge and whose objective is the optimal use of available resources. The Organisation has mainly worked with hill sheep, some of this work being briefly described in this article, but in recent years its activities have been extended to include upland sheep, beef cattle and red deer. 
The basic resources of hill sheep farming are the areas of hill and upland classified as rough grazings in the United Kingdom agricultural statistics. These are uncultivated pastures often at altitudes greater than $230 \mathrm{~m}$ above sea level. About one-third (4.S million ha) of the agricultural land in the United Kingdom falls into this category. It occurs predominantly in Scotland, Wales, the Pennines and north of England, parts of south-west England, and the upland area of Northern Ireland. The rough pastures occur on a wide range of soils and are composed of a wide variety of vegetation types, varying from the acid grasslands of the drier east (predominantly Agrostis tenuis, A. canina, Festuca ovina and F. rubra - warm summers and cold winters: low to medium rainfall (e.g., 7.50 to $1300 \mathrm{~mm}$ ); 170 to 190 growing days per year), to the blanket bog communities found on deep peat in the west and north (predominantly $\mathrm{Cal}$ I una vulgaris, Erica tetralix. Eriophorum augustifolium, E. vaginatum, Tricophorium cespitosum and Sphagnum sp. - cool summers and mild winters; high rainfall (over $1500 \mathrm{~mm}$ ) ; 190 to 200 growing days per year).

These resources carry about 5.4 million hill ewes (i.e., pure native breeds adapted to hill conditions, predominantly of the Blackface type, e.g., Scottish Blackface, Cheviot — South and North Country hill, Welsh Mountain, Swaledale, Herdwick, Rough Fell, Derbyshire Grittstone), 2.2 million upland ewes (some pure breeds, e.g., Exmoor, Cheviot - North Country park, Kerry Hill, Clun, but mainly first crosses of longwool fast growing breeds, with native hill breeds, e.g., Greyface cross from Border Leicester ram and Scottish Blackface ewe), and 0.7 million beef breeding cows. Production is primarily of store animals which are transferred to better lowland farms for finishing. Stocking rates are low and in traditional systems of hill sheep farming the ewes are set-stocked throughout the year and the stocking rate per unit area is limited to the number which can be fed from grazed pasture throughout the winter months.

The result is marked under-utilization of the pasture grown in the short growing season (5 to 6 months). Individual animal output is low, lambing percentages varying from 55 to over 100; lamb growth rates are modest, resulting in an output of liveweight per hectare varying from 2 to $25 \mathrm{~kg}$ 'per year, Average flock size is about 1000 ewes per farm and one shepherd may look after from 500 to 3000 ewes. Farm business size is small economically and the industry has to live with uncertain pro- 
duct prices, partly because of the need to sell store lambs in a short period at the end of the pasture growing season.

The early work of the Organisation analysed the biological components of traditional systems. The result led to the synthesis of an improved system of hill sheep farming based on a "twopasture" concept which has been successfully tested on two of the Organisation's farms since 1968 and which is now being tested on several commercial farms in Scotland and on ADAS (Agricultural Development Advisory Service) experimental husbandry farms in England and Wales. The principle of the new system is to improve a small area of the hill pasture and to graze this area at key times in the animal's nutrition cycle i.e, during lactation and early lamb growth and prior to mating. The system also requires that the pregnant ewe be given supplementary concentrate food in the six weeks prior to parturition. The operation of these ideas has resulted in increased stocking rates, in better individual animal performance, in higher lambing percentages, and hence in greater production of weaned lamb and wool.

For example, on the acid grassland at Sourhope, the improved pasture consists of about 100 of the total 283 ha. The improved area is enclosed into a series of paddocks of which -only 10 ha were reseeded with ryegrass/white clover and 11.3 ha were sprayed to eradicate bracken. By using the enclosed pastures in the manner described above between 1969 and 1976, stock numbers have increased from 398 to 620 , weaning percentage from 84.7 to 108.5 , and total weight of lamb weaned from 7785 to $17902 \mathrm{~kg}$, and of wool from 850 to $1543 \mathrm{~kg}$. On the blanket bog at Lephinmore, 95 out of 444 ha have been enclosed to form the improved pasture but within 69 of these hectares of unimproved Calluna and Eriophorum moorland only $35 \%$ of the area has been surface-seeded on a mosaic basis to give patches of improved ryegrass, timothy and white clover pasture. In this case between 1969 and 1976 stock numbers have increased from 339 to 458 , weaning percentage from 85 to 91 and total weight of lamb weaned from 7207 to $9701 \mathrm{~kg}$, and of wool from 652 to $915 \mathrm{~kg}$.

The enhanced income from the operation of the principles of the system has been shown to be sufficient to repay the capital invested in land improvement and in extra stock within four years on the grassy hill and within eight to nine years on the blanket bog. Not only are "two-pasture" systems under trial in the field, but with experience and understanding of the biology 
of their operation it has been possible to devise mathematical models which will simulate the use of similar hill sheep systems in many other environments and with a wide variety of constraints. Thus, it is possible to build up a likely response curve to a range of inputs over a wide spectrum of resources and climatic regions and so design economically viable systems of hill sheep farming to suit any of the contrasted hill areas of the United Kingdom.

The research work of the Organisation, whose context is set by the biological needs of two-pasture systems and by financial considerations, falls into two departments - Animal Production and Nutrition, and Plants and Soils.

The Animal Production and Nutrition department is concerned with nutritional studies on the various components of performance (fertility, lactation, lamb growth and pregnancy) in both sheep and cattle. The work of the department also includes studies on the nutritive value of hill plant material, diet supplementation and diet selection in hill sheep and cattle. The studies of systems development are also included in this department's programme.

The aim of the Plants and Soils department is to increase production of good quality pasture on the hills and uplands, in studying mineralization of plant nutrients from soil, the germination and establishment of seeds in hill soils, plant nutrition, in particular the requirements for lime, phosphate, potassium, and trace elements, the optimum conditions for rhizobial inoculation and nitrogen fixation by white clover, the need for mycorrhiza, pasture improvement by grazing control and/or use of herbicides, the growth of heather and its nutritional value to livestock in a joint programme, the effect of utilization of pasture on its regrowth, and nutrient cycling through soil-plant-animal systems.

There is also a small programme, conducted in collaboration with the Rowett Research Institute, Aberdeen, to explore the potential of the red deer as a domesticated animal and to examine the effects of utilization by this animal on hill pastures. 